\title{
RURAL RESIDENTS' PERCEPTIONS ON ECONOMIC IMPACTS OF CULTURAL AND PROMOTIONAL ASPECTS OF TOURISM
}

\author{
Aleksandra Vujkol, Olgica Zečević Stanojevićz, Leposava Zečevićn, \\ Dragan Nedeljković, Milija Zečevićs \\ *Corresponding author E-mail: aleksandravujko@yahoo.com
}

\begin{abstract}
A R T I C L E I N F O
Review Article

Received: 02February 2020

Accepted: 18 February2021

doi:10.5937/ekoPolj2101155V

UDC 316.72:338.48-44(1-22)

\section{Keywords:}

rural destinations, employment, culture, marketing, residents' perceptions, tourism, Fruška Gora mountain

JEL: E24, O15, R11

\section{A B S T R A C T}

This study investigates residents' attitudes to tourism impacts (marketing, culture etc.) on Fruška Gora Mountain (Serbia), within the larger framework of economic impacts. The correspondence analysis of the perception of local residents showed that residents have a generally positive attitude towards the development of tourism considering its economic aspects, and then the desk study show edjustification of positive attitudes, thus confirming the main hypothesis. According to the analysis of the opinions of the local residents, it was found that the local residents positively perceived economic impact of tourism in two aspects: through increase in number of employees (employment and self-employment) as well as through the development of the community. The development of tourism in any destination in evitably leads to an increase of domestic and foreign investment, which then leads to the construction of infrastructure and suprastructure facilities, the introduction of various tourist taxis, and if it is possible, as it is the case with Fruška Gora Mountain, it can lead to a successful cross-border cooperation.
\end{abstract}

(C) 2021 EA. All rights reserved.

1 Aleksandra Vujko, Assstant Professor, University of Business Studies, Faculty of Tourism and Hotel Management, Jovana Dučića 23a, Banja Luka 78000, Republic of Srpska; Phone: +381 649142645 , E-mail: aleksandravujko@yahoo.com; ORCID ID (https://orcid.org/0000-0001-8684-4228)

2 Olgica Zečević Stanojević, Full Professor, Faculty of European Business and Marketing, Vojvode Dobrnjca 15, Belgrade 11000, Serbia, Phone: +381 11 3225598, E-mail: olgicazecevic.stanojevic@febm.edu.rs

3 Leposava Zečević, Full Professor, Faculty of European Business and Marketing, Vojvode Dobrnjca 15, Belgrade 11000, Serbia, Phone:+381 113225598 E-mail: leposava.zecevic@febm.edu.rs

4 Dragan Nedeljković, Full Professor, Faculty of European Business and Marketing, VojvodeDobrnjca 15, Belgrade 11000, Serbia, Phone: +381 642671 577, E-mail: draganedeljkovic62@gmail.com

5 Milija Zečević, Emeritus, Faculty of European Business and Marketing, Vojvode Dobrnjca 15, Belgrade 11000, Serbia, Phone: +381 64615 0970, E-mail: febmeu@gmail.com 


\section{Introduction}

There are a few visible positive impacts of tourism on the Destination development. Tourism has enabled the survival of small population settlements, and those with a more favourable position and the various featuresand other advantages may experience the population growth and immigration character. Tourism is often seen as an activity that affects the emancipation of women and increasing women's labour force activity. It is understood that the process of emancipation of women maybe more or less depending on the dynamic selection of the main directions of development of society, i.e. which economic activities will be given priority in the development, and whether the activity directly engageswomen, which is interpreted as the main factor of emancipation. However, economic impact of tourism on the destination development is the most tangible and takes upall the other effects in the long term perspectives.

The paper deals with the impact of cultural and promotional aspects of tourism on employment as an economic factor, and the development of the community through domestic and foreign investment, construction of infrastructure and supra-structural network, introduction of tourist taxis, as well as the benefits of cross-border cooperation (Purcell \& Nevins 2005; Nunkoo\&Ramkissoon 2011; Latkova\& Vogt 2012). Employment is seen in the broader context of the new jobs, either in the private or public sector. Primarily through its multiplicative effect.

Therefore, the attempt of sizing the impact of cultural and promotional aspects of tourism on the growth of employment should statistically follow not only those who are directly employed in the tourism and hospitality industry, but also the employees in the activities that are an integral part of a complex of tourist services, and which are reflectedin the structure of tourism spending. In a narrow sense, it is the service sector: transport, trade, tourism and intermediary activities, which could not be developed only by theconsumption of the local population (Nunkoo \& Ramkissoon 2011; Latkova \& Vogt 2012). Besides, there are a large number of people who actively participate in the formation of tourism, but by the formal and methodological point of view they belong to the category of the inactive population. It is primarily related to the female labour forcein the households.

Households in tourist regions, where there is the process of urbanization with the help of tourism development, show the orientation to non-agricultural activities and new ways of economic engagement of households. The changes in household are a reflection of adaptation to new socio-economic circumstances and show the totality of social transformation in the economic, demographic and social plan (Liu and Wall 2006). For example, the importance that the household had before the collapse of traditional patriarchal community is getting a new modality with the development of tourism.

Although it is no longer based on the traditional family manufacture, economic activity in family households, due to providing tourist services, returns to the household longlost functions. It should be borne in mind that the specific types of tourist service, their economic effects on the household income, the seasonal nature, the possibility of in- 
volvement of all household members of different ages and gender and many other features represent an interesting and rewarding field for considerable scientific research. The infrastructure is the basis for economic development and it is the responsibility of the state and its institutions, such as roads, health care system, electricity, water, public services, police, airports, libraries and others, while tourism superstructure represents an additional set of infrastructure upgrade, such as hotels and other accommodation, restaurants, theme parks, golf courses and the like.

The development of the infrastructure is focused on the marketing promotion and creation of conditions for economic and social development, and improving the competitiveness of the region through the construction and modernization of infrastructure according to European standards. The construction of infrastructure and superstructure will create the preconditions for the generation of new jobs and also attract investment, improve the quality of life and standard of living and reduce pressure on the environment through the optimization of water resources, water treatment plants, reducing $\mathrm{CO}_{2}$ emissions and solid waste management. The tourist fees and their amount are determined the municipality, per guest. In addition, there are certain"tourist areas" in which a tourist fee is charged for the development and $80 \%$ goes to the municipal funds and $20 \%$ to the Republic fund of tourist development (www.mfp.gov.rs).

Fruška Gora Mountain is located on the border with the Republic of Croatia (Vujko \& Plavša 2010) and the encourage men to cross-border cooperationwould enable the improvement of the regional economy in a socially andenvironmentally sustainable manner and at the same time good neighbourhood relations will be promoted (www. croatia-serbia.com). Bearing in mind that households are places where the process of tourist acculturation occurs and where the standards of living and thinking are changed, the aim of this study is to show with the help of the opinion of the local residents the possible economic effects that could be achieved with the development of tourism on Fruška Gora. Owing to these economic effects, tourism makes changes to all households, and not only to those that are directly involved in tourism.

This article reports the findings of a survey of attitudes of residents living in a rural region of Fruška Gora Mountain (Serbia) towards a proposed tourism venture prior to its development. The survey method was applied for the purposes of this research, whereby 250 questionnaires were distributed and 249 of them were analyzed. This analysis led to the confirmation of the given hypothesis and refutation of other hypotheses. The SPSS program, version 20.0, and Pearson Chi-Square Test were used. In addition to the research data, the authors used the available statistical and secondary documentation.

\section{Theoretical Background}

Tourism, as practiced in developed countries, is essentially an economic endeavour, where as in developing countries it is mainly about leisure consumption as a path to development (Hung-Lee \&Haun-Jan, 2019; Vujko et al. 2019; Vunjak et al. 2020). This consumption generates jobs and tourism may be the only remunerative employment 
possibility in poor and peripheral regions where few other options are available to improve their marginal economic status (Almeida-Santos \&Buzinde 2007; Andriotis\& Vaughan 2003; Ishikawa \&Fukushibe 2006; Lepp 2007; McGehee\&\&ereck 2004; Ryan \& Cave 2005; Zhang et al. 2006; Vargas-Sanchez et al. 2010). Tourism has a high need for human capital and offers a diversity of jobs in a variety of operations of varied sizes and types (Szivas et al. 2003). However, since local people in the developing world are usually unfamiliar with the workings of a service economy, tourism is often institutionalized and manipulated predominately by bureaucratic initiatives (Liu and Wall 2006; Podovac et al. 2019).

There appears to be a general oversight by governments to address "the connection between education, ability to deliver a quality tourism experience and the need to develop a sustainable tourism industry" (Hung-Lee \&Haun-Jan, 2019). It is only since the 1970 s that the resident began to receive more attention, as shown by the increased number of studies and by the research objectives and methods utilized in the study of residents' attitudes (Almeida-Santos \&Buzinde 2007; Andriotis\& Vaughan 2003; Ishikawa \&Fukushibe 2006; Lepp 2007; McGehee\&Andereck 2004; Ryan \& Cave 2005; Zhang et al. 2006; Vargas-Sanchez et al. 2010; Berić\&Jovičić 2012; Brankov et al. 2015; Srdanović\&Pavić 2015).

Tourism is commonly used as a tool to stimulate marginal economies and to promote development through the jobs and incomes that it can foster (Purcell \& Nevins 2005; Bramwell 2011; Ruhanen 2013). Although not always explicitly stated, it is often hoped that it will reduce hardships through the promotion of upward labour mobility. However, the experience with tourism is varied, mainly due to heterogeneity (Vujko\&Plavša 2014) and also because of the varying abilities of destinations to meet different needs. Thus, there is no widely accepted consensus on what tourism brings to the destination. In that context, tourism is seen as a tool of promotional activities (Podovac et al. 2019; Gajić et al. 2018; Gajić et al. 2019). Decision-making in such tourism developments is predominately based on the interventions of government agencies and large tourism firms, resulting in the dominance of external, often foreign, capital and the marginalization of local people. Local residents are frequently under-represented in the tourism development, both as investors and decision makers (Vuković et al. 2019). This is because they lack knowledge of tourism and associated skills, and because of the priority placed upon economic growth by the policymakers, with little concern for equity.

Most importantly, as part of promotional activitiesit will enhance the lives of local people and, as such, tourism planning should be as much about planning for residents as planning for visitors. In a developing economy, deficiencies in human capital, albeit with a labour surplus with low skills and qualifications and lack of tourism expertise, have been a major obstacle preventing the host population from participating effectively in tourism employment. Residents of any host area may perceive tourism in a positive way because of its potential for job creation, income generation, and enhanced community infrastructure, as has been found in many host communities (Saveriades 2000; Mitchell \& Reid 2001). 
Alternatively, the residents of host areas may perceive tourism in a negative way because of the socio-cultural and environmental costs, as has also been found in many host communities (e.g. Chen 2000). Dubois and Dubois (2012) recognize that embedding sustainability throughout an organization requires simultaneous consideration of economic, social, and environmental sustainability. More likely, residents will be aware of the positive and negative implications of tourism and will draw their conclusions based on the relative weightings they attach to the benefits and the costs. Many commentators (e.g. Hung-Lee \&Haun-Jan, 2019; Vujko et al. 2019; Vunjak et al. 2020) have suggested that this balance of residents' perceptions of the costs and benefits of tourism is a major factor in visitor satisfaction and is, therefore, vital for the success of the tourism industry.

Thus, awareness of residents' perceptions of tourism development and its impacts can help planners and developers to identify real concerns and issues for appropriate policies and action to take place, optimizing the benefits and minimizing the problems. There is increasing evidence that residents of communities that attract tourists hold diverse opinions about development in their region (Kuvan\& Akan 2005). This diversity of opinion has sparked increasing amounts of research into resident attitudes over the past two decades (Mason \& Cheyne 2000).

\section{The research methodology}

This study was conducted on Fruška Gora Mountain, located in Vojvodina, Serbia. The region is one of the fastest-growing areas of Serbia. The first partofthis research was thefield researchand data collectionthroughdirect examinationthat was conductedin the area of Fruška Gora Mountain. We examined the local population of seven places on Fruška Gora Mountain: Petrovaradin, Sremski Karlovci, Čortanovci, Ledinci, Sremska Kamenica, Erdevik and Banstol. The survey was conducted between May and August 2018 , and the questionnaire consisted of questions grouped into independent and dependent variables.

The independent variable is a group of questions related to gender, age structure and education. The dependent variables reflect the opinion of the participants about the influence that tourism has on their lives and their households. The starting point of the study was the hypothesis $\mathrm{H}$ stating that tourism has a positive economic effect on the local residents. The first question imposed to the participants was whether tourism has an impact on their lives. It is worth while mentioning that all of the 249 analyzed questionnaires had an affirmative answer, which actually encouraged further research.

The next variables that were singled out showed the actual opinion of local people about tourism development on Fruška Gora Mountain. There were two groups of variables. In the first group of variables there were questions concerning the purely economic impact. One of the most notable questions is: How advantageous are the impacts of tourism on employment? Within this group of variables the lower-level hypothesis (h1) has been set: h1 - Tourism creates more jobs. In the second group of variables 
there were questions concerning the impact of tourism on their lives and on the entire local community.

The question that was particularly noted is: How advantageous are the impacts of tourism on the region's economy? Within this group ofvariables the lower-level hypothesis has been set: h2 - Tourism attracts more investment in the region; h3 - Tourism provides construction of hotels and other tourist facilities; h4 - Tourism has led to an increase in infrastructure for local people and h5 - The fees provide better conditions for the development of tourism; h6 - Tourism development would have an impact on cross-border cooperation.

In the area of Fruška Gora Mountain it is possible to achieve cross border cooperation. This leads to the lower-level hypothesis h6 - Tourism development would have an impact on cross-border cooperation. The second part of the paper includes the desk research. The methodology involved the perusal of official government documents available to the public. In fact, the subject of interest was the incentives provided by the Autonomous Province of Vojvodina in the economic development of tourism, particularly government subsidies and loans in order to reduce unemployment. The available sites and all supporting documentation of the relevant state institutions were investigated, such as: Vojvodina Investment Promotion, Provincial Secretariat of Finance, Provincial Secretariat for Interregional Cooperationand Local Government, Ministry of Finance of the Republic of Serbia and IP Across-border project between Serbia and Croatia.

\section{Results and discussion}

Out of the 250 questionnaires, 249 were analyzed, and the participants in this survey were residents of the mountain in the following structure: Petrovaradin $(41.8 \%)$, Sremski Karlovci (12.4\%), Ledinci (12\%), Črtanovci (10.4\%), Banstol (6.8\%) and Erdevik $(6.8 \%)$. Regarding the age structure of the visitors, the survey included $61.4 \%$ of the male population and $38.6 \%$ of women. The largest percentage of them $(51.0 \%)$ was aged between 31 and50, followed by $42.2 \%$ over 51 , those aged between 16 and 30 $(2.1 \%)$, whereas the lowest participants were below $15(1.7 \%)$. The largest percentage of them (78.5\%) completed secondary school education, followed by $10.7 \%$ with university degree; $5.8 \%$ with college; $4.5 \%$ with elementary education, and $0.4 \%$ with $\mathrm{MSc} / \mathrm{PhD}$ degree. The locals were asked to list the main economic impacts of tourism in their communities. Open-ended responses to this question were categorized into different types of economic impacts. The following two categories emerged: economic impacts and community development.

\section{Economic impacts}

Tourism is an economic sector of Vojvodina with the prospect of becoming one of the key pillars of its development and significant revenue, with areas ofEastern and Central Europeas primary markets. In Vojvodina the investments totalled 211 million euros of investment in 2019, whereby 5,267 people were employed (www.vip.org.rs). The results can be seen in Table 1 showing that $17.6 \%$ of male participants believe that the 
positive aspects of tourism development in the regionwould be reflected in employment opportunities and creating a new jobs. The high percentage ofthem $(81 \%)$ believes that the great advantage of tourism is self-employment. It is similar among the female participants. Of all female participants, $28.1 \%$ said that being employed is an advantage of tourism development, while $64.6 \%$ of them said it is self-employment.

Table 1. The advantageous of tourism on employment

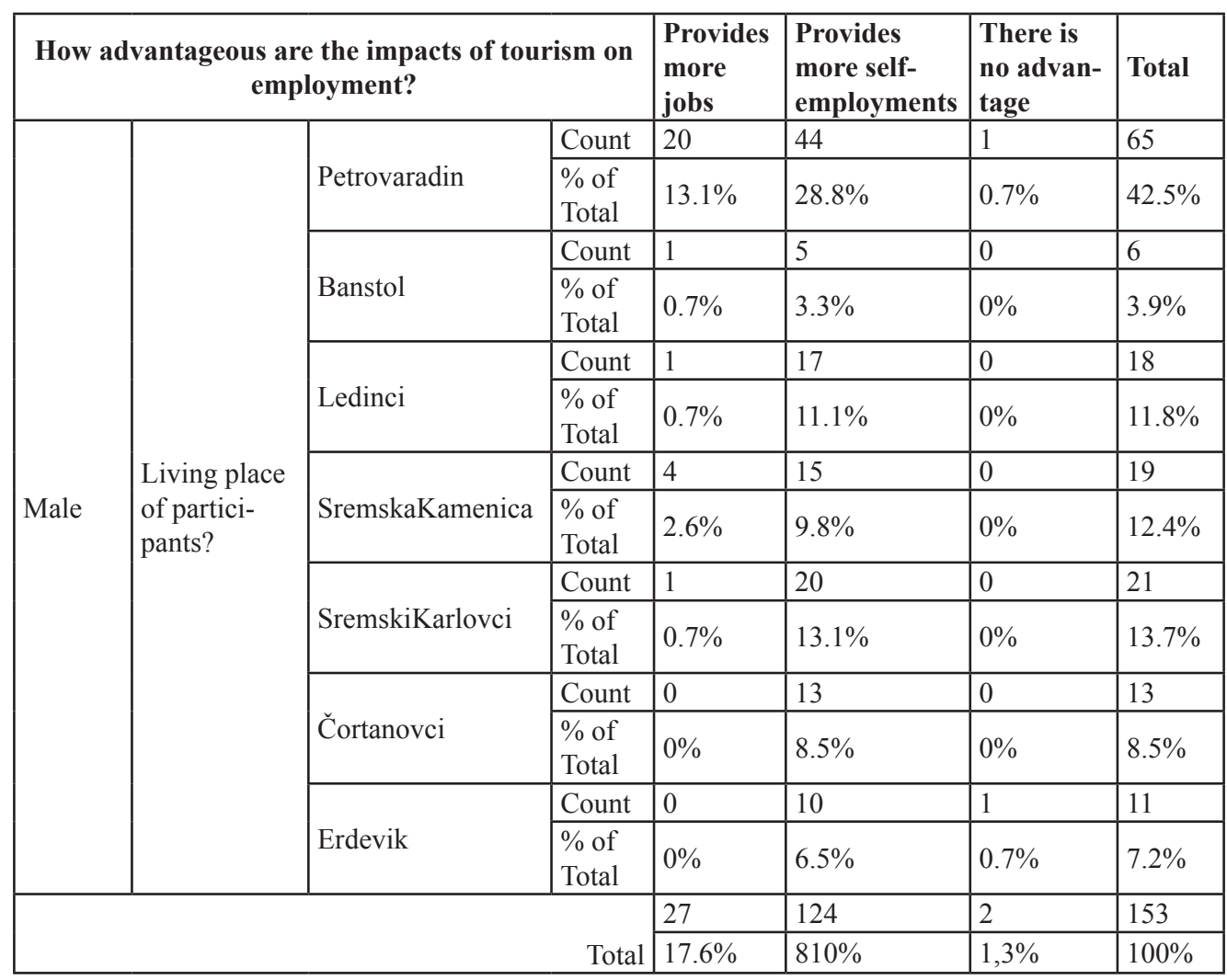




\begin{tabular}{|c|c|c|c|c|c|c|c|}
\hline \multicolumn{4}{|c|}{$\begin{array}{l}\text { How advantageous are the impacts of tourism on } \\
\text { employment? }\end{array}$} & \multirow{2}{*}{\begin{tabular}{|l}
$\begin{array}{l}\text { Provides } \\
\text { more } \\
\text { jobs }\end{array}$ \\
8 \\
\end{tabular}} & \multirow{2}{*}{\begin{tabular}{|l|}
$\begin{array}{l}\text { Provides } \\
\text { more self- } \\
\text { employments }\end{array}$ \\
27 \\
\end{tabular}} & \multirow{2}{*}{$\begin{array}{l}\text { There is } \\
\text { no advan- } \\
\text { tage }\end{array}$} & \multirow{2}{*}{$\begin{array}{l}\text { Total } \\
39\end{array}$} \\
\hline \multirow{14}{*}{ Female } & \multirow{14}{*}{$\begin{array}{l}\text { Living place } \\
\text { of partici- } \\
\text { pants? }\end{array}$} & \multirow[b]{2}{*}{ Petrovaradin } & Count & & & & \\
\hline & & & $\begin{array}{l}\% \text { of } \\
\text { Total }\end{array}$ & $8.3 \%$ & $28.1 \%$ & $4.2 \%$ & $40.6 \%$ \\
\hline & & \multirow[b]{2}{*}{ Banstol } & Count & 2 & 9 & 0 & 11 \\
\hline & & & \begin{tabular}{|l|}
$\%$ of \\
Total \\
\end{tabular} & $2.1 \%$ & $9.4 \%$ & $0 \%$ & $11.5 \%$ \\
\hline & & \multirow[b]{2}{*}{ Ledinci } & Count & 2 & 9 & 1 & 12 \\
\hline & & & $\begin{array}{l}\% \text { of } \\
\text { Total }\end{array}$ & $2.1 \%$ & $9.4 \%$ & $10 \%$ & $12.5 \%$ \\
\hline & & \multirow[b]{2}{*}{ SremskaKamenica } & Count & 2 & 2 & 1 & 5 \\
\hline & & & $\begin{array}{l}\text { \% of } \\
\text { Total }\end{array}$ & $2.1 \%$ & $2.1 \%$ & $10 \%$ & $5,2 \%$ \\
\hline & & \multirow[b]{2}{*}{ SremskiKarlovci } & Count & 3 & 7 & 0 & 10 \\
\hline & & & $\begin{array}{l}\% \text { of } \\
\text { Total } \\
\end{array}$ & $3.1 \%$ & $7.3 \%$ & $0 \%$ & $10.4 \%$ \\
\hline & & \multirow[b]{2}{*}{ Čortanovci } & Count & 4 & 8 & 1 & 13 \\
\hline & & & $\begin{array}{l}\% \text { of } \\
\text { Total }\end{array}$ & $4.2 \%$ & $8.3 \%$ & $10 \%$ & $13.5 \%$ \\
\hline & & \multirow[b]{2}{*}{ Erdevik } & Count & 6 & 0 & 0 & 6 \\
\hline & & & $\begin{array}{l}\text { \% of } \\
\text { Total }\end{array}$ & $6.3 \%$ & $0 \%$ & $0 \%$ & $6.3 \%$ \\
\hline \multirow{2}{*}{\multicolumn{4}{|c|}{ Total }} & 27 & 62 & 7 & 96 \\
\hline & & & & $28.1 \%$ & $64.6 \%$ & $7.3 \%$ & $100 \%$ \\
\hline
\end{tabular}

Source: Own calculations

Considering the fact that the residents of these places gave similar answers, the results seen in Table 2 that there were no statistically significant differences in responses in relation to their gender and place of residence. Bearing in mind the percentage of participants who responded in favour of self-employment, there was an increasing interest in their opinions about what they would do provided that it is directly linked to the development of tourism. The results seen in Table 3 show that the highest percentage of participants gave the following answers: nurturing of old crafts $(18.1 \%)$, production of wine and brandy (16.5\%), handiwork (15.7\%), making souvenirs $(14.9 \%)$ and manufacture of traditional cheese and dried meat products $(9.6 \%)$.

Table 2. Pearson Chi-Square Test

\begin{tabular}{|l|l|l|l|}
\hline & Value & df & Statistical significance $(\mathrm{p})$ \\
\hline Pearson Chi-Square Test Male & 23.378 & 12 & 0.025 \\
\hline & Value & df & Statistical significance (p) \\
\hline Pearson Chi-Square Test Female & 21.879 & 12 & 0.039 \\
\hline
\end{tabular}

Source: Own calculations 
After examining the Table 4 it can be concluded that there is a statistically significant difference in responses because in the results there were answers of the participants who answered the previous question that benefits of tourism development are reflected in the creation of new jobs and having an employer $(25.3 \%)$. The total percentage of those who put self-employment as an advantage was $74.8 \%$, which gave a good foundation for further research. Starting from the assumption that eachdestination has something that makesit different from other areas, it was concluded that the success of tourism development depends on the compatibility of the population that lives there.

Table 3. The most common forms of self-employment

\begin{tabular}{|c|c|c|c|c|c|c|c|}
\hline \multicolumn{8}{|c|}{ What are the most common forms of self-employment? } \\
\hline & $\begin{array}{c}\text { Manufacture } \\
\text { of traditional } \\
\text { cheeses and } \\
\text { dried meat } \\
\text { products }\end{array}$ & $\begin{array}{l}\text { Production } \\
\text { of wine and } \\
\text { brandy }\end{array}$ & Handiwork & $\begin{array}{l}\text { Nurturing of } \\
\text { old crafts }\end{array}$ & $\begin{array}{l}\text { Making } \\
\text { Souvenirs }\end{array}$ & $\begin{array}{l}\text { I do not } \\
\text { know }\end{array}$ & Total \\
\hline \multirow{2}{*}{ Male } & 17 & 22 & 37 & 18 & 30 & 29 & 153 \\
\hline & $6.8 \%$ & $8.8 \%$ & $14.9 \%$ & $7.2 \%$ & $12 \%$ & $11.6 \%$ & $61.4 \%$ \\
\hline \multirow{2}{*}{ Female } & 7 & 19 & 2 & 27 & 7 & 34 & 96 \\
\hline & $2.8 \%$ & $7.6 \%$ & $0.8 \%$ & $10.8 \%$ & $20.8 \%$ & $13.7 \%$ & $38.6 \%$ \\
\hline \multirow[b]{2}{*}{ In total } & 24 & 41 & 39 & 45 & 37 & 63 & 249 \\
\hline & $9.6 \%$ & $16.5 \%$ & $15.7 \%$ & $18.1 \%$ & $14.9 \%$ & $25.3 \%$ & $100 \%$ \\
\hline
\end{tabular}

Source: Own calculations

Table 4. Pearson Chi-Square Test

\begin{tabular}{|l|l|l|l|}
\hline \multirow{2}{*}{ Pearson Chi-Square Test } & Value & df & Statistical significance $(\mathrm{p})$ \\
\cline { 2 - 4 } & 41.412 & 5 & 0.000 \\
\hline
\end{tabular}

Source: Own calculations

The mosaic of cultural heritage of Sremis something that only Vojvodinacan offer to the tourist market of Europe. Nowhere else on the old continent such ethnic diversity can be found. Most important is that this diversity is still active in the villages, towns and low land areas. In addition to forms, ethnic tourism product, at least in terms of resources, has clearly marked and identifiable elements, i.e.forms ofexpression. Hence, it may be noticed that the local residents believe tha tall of these symbols and recognition of cultural factors should be very fied through the development of tourism (Table 5). This therefore leads to the confirmation of the lower-level hypothesis: h1 - Tourism creates more jobs. 
Table 5.Examplesof someproducers of traditionalproducts andhandicrafts on the Fruška Gora Mountain

\begin{tabular}{|c|c|c|}
\hline Name & Place & Description of the proposal \\
\hline $\begin{array}{l}\text { Winegrowers Association } \\
\text { "Saint Tryphon" }\end{array}$ & Banoštor & $\begin{array}{l}\text { On the area of } 80 \text { hectares are cultivated Alliance Ries- } \\
\text { ling, Chardonnay, Traminac, Merlot, Cabernet Sauvignon, } \\
\text { Cormorant, Cabernet franc, Franconia, Burgundy, Ham- } \\
\text { burg, pink wine and dessert wine Bermet. Annual wine } \\
\text { production is up to } 150000 \text { litres. }\end{array}$ \\
\hline NebojšaVeselinović & Rakovac & $\begin{array}{l}\text { Souvenirs made of wood, clay, plaster, painted bottles, } \\
\text { pepper tiles, ceramics etc. }\end{array}$ \\
\hline Vera Žigić & Rakovac & Icon paintings on mushrooms \\
\hline ZlatkoSkender & Rakovac & Production of organic wooden toys and souvenirs \\
\hline $\begin{array}{l}\text { Women's Associa- } \\
\text { tion "Mountain Rose" }\end{array}$ & Rakovac & $\begin{array}{l}\text { Founded on January } 16,2009 \text {. Its aim is to promote wom- } \\
\text { en's art, old art and cultural tradition of the region in which } \\
\text { they live. Charity and souvenirs are also recognized } \\
\text { when it comes to this association. }\end{array}$ \\
\hline BrankaJukić & Beočin & Iconographer (Byzantine icon painting) \\
\hline $\begin{array}{l}\text { The Association of wom- } \\
\text { en "Danubian Flower" }\end{array}$ & Beočin & $\begin{array}{l}\text { Craftsmen's traditional techniques of embroidery and } \\
\text { making gold embroidery. }\end{array}$ \\
\hline Beekeeping "Bikar" & $\begin{array}{l}\text { SremskiKar- } \\
\text { lovci }\end{array}$ & $\begin{array}{l}\text { Family firm "Beekeeping Bikar," offers a wide range of } \\
\text { honey and honey products. Available to everyone are } \\
\text { linden, acacia, meadow and many others. There are } \\
\text { also wine, honey, vinegar, honey and various prepara- } \\
\text { tions for body care made from bee products. }\end{array}$ \\
\hline $\begin{array}{l}\text { Non-governmental organi- } \\
\text { zations: Association for Re- } \\
\text { construction and develop- } \\
\text { ment of SremskiKarlovci }\end{array}$ & $\begin{array}{l}\text { SremskiKar- } \\
\text { lovei }\end{array}$ & $\begin{array}{l}\text { Non-governmental organizations mainly gathers women } \\
\text { from SremskiKarlovci and has been active in projects in } \\
\text { the field of environment, promotion of women's rights } \\
\text { and traditional crafts of SremskiKarlovci. Today, the or- } \\
\text { ganization works to promote the old methods of produc- } \\
\text { tion of garments made of wool, so called. technique "pus- } \\
\text { tovanja". }\end{array}$ \\
\hline Karlowitzd.o.o. & $\begin{array}{l}\text { SremskiKar- } \\
\text { lovei }\end{array}$ & $\begin{array}{l}\text { The offer of the German Association of Danube is a lot of } \\
\text { interesting things. Certainly, the most famous is tradition- } \\
\text { al cake "kuglof" to which are added various spices, wine, } \\
\text { fruit and more. }\end{array}$ \\
\hline KeramikaRas & $\begin{array}{l}\text { SremskiKar- } \\
\text { lovei }\end{array}$ & $\begin{array}{l}\text { There is a family business that for many years engaged } \\
\text { in the production of ceramics. These cases are a vari- } \\
\text { ety of motives of SremskiKarlovci, Vojvodina, Serbia. }\end{array}$ \\
\hline KoviljkaŽivanov & $\begin{array}{l}\text { SremskiKar- } \\
\text { lovci }\end{array}$ & Creating embroidered handicrafts \\
\hline PetarEror & Rivica & $\begin{array}{l}\text { Traditional meat products: sausages, ham, "kulensau- } \\
\text { sage", bacon. }\end{array}$ \\
\hline ZoricaAvramović & Rivica & Production of specific types of cheese and dairy products \\
\hline GajaPetričević & Rivica & Production of traditional brandy so-called "rakija". \\
\hline StevanGoljevački & Irig & $\begin{array}{l}\text { Souvenirs of wood, typical items of Vojvodina - } \\
\text { mill, sweep, cart, windmills etc. }\end{array}$ \\
\hline DraginjaBudimčić & Irig & $\begin{array}{l}\text { Souvenirs such as fridge magnets in the shape of the re- } \\
\text { lief of Irig, knit bubble of gypsum (wine), vineyard keep- } \\
\text { er etc. }\end{array}$ \\
\hline Vera Mulaji & Irig & Production of various types of homemade cakes \\
\hline
\end{tabular}




\begin{tabular}{|l|l|l|}
\hline \multicolumn{1}{|c|}{ Name } & \multicolumn{1}{|c|}{ Place } & \multicolumn{1}{c|}{ Description of the proposal } \\
\hline The Hunting Society “Zec" & Vrdnik & $\begin{array}{l}\text { Hunting, trapping, farming and wildlife protection. Hunt- } \\
\text { ing of pheasants and other wildlife in the commercial } \\
\text { and tourism purposes. }\end{array}$ \\
\hline $\begin{array}{l}\text { "Bonsai park" exhibition } \\
\text { space }\end{array}$ & Vrdnik & $\begin{array}{l}\text { Bonsai Park - the exhibition park, only in Serbia, a perma- } \\
\text { nent exhibition space, 60 trees from Fruska Gora. In the } \\
\text { park there are rare species of trees about 250 years old. } \\
\text { The garden has herbs: geranium, sage, selenium, mint, } \\
\text { myrtle, bonsai, etc. }\end{array}$ \\
\hline MilošTešić & Jazak & $\begin{array}{l}\text { Creating new and repair of old carriages, wheels, and } \\
\text { other necessary parts. }\end{array}$ \\
\hline Farm by Perko & Neradin & $\begin{array}{l}\text { Its beauty and attractiveness represents a large collec- } \\
\text { tion of antiquities, such as yokes, wagon, ploughs, looms, } \\
\text { wooden beds and mattresses, mirrors hand-made blan- } \\
\text { kets, two hundred years old, which completes the kind- } \\
\text { ness and hospitality of the host. }\end{array}$ \\
\hline
\end{tabular}

Source: research of the authors

\section{Community development}

Local economic development is a process through which individual stakeholders within the community work together with partners from public life, business and nongovernmental sector in order to create better conditions for economic growth and new jobs. Through this process, they establish and maintain a dynamic entrepreneurial culture and create a new community and business prosperity ino rder to improve the quality of life for al lin the community. The results can be seen in Table 6 showing how the participants rated the impact of tourism on local economic development.

Both male participants (35.9\%) and female participants (14.6\%) said that the impact of tourism would have a positive effect on attracting investment while $24.8 \%$ of male participants and $44.8 \%$ of female participants said that it might lead to the construction of hotels and other tourist facilities. This therefore leads to the confirmation of the lower-level hypothesis: h3 - Tourism provides construction of hotels and other tourist facilities. The following item was infrastructure as replied by male participants (20.9\%) and female participants $(17.7 \%$ ), while $12.4 \%$ of male and $15.6 \%$ of female participants emphasized the benefits fromvarious touristtaxes. 
Table 6. The advantageous of the tourism impacts on the region's economy

\begin{tabular}{|c|c|c|c|c|c|c|c|c|c|}
\hline \multicolumn{4}{|c|}{$\begin{array}{l}\text { How advantageous are the impacts of tourism } \\
\text { on the region's economy? }\end{array}$} & \multirow[t]{2}{*}{$\begin{array}{l}\text { Invest- } \\
\text { ment }\end{array}$} & \multirow[t]{2}{*}{\begin{tabular}{|l} 
Construc- \\
tion of \\
hotels and \\
other tour- \\
ist facili- \\
ties \\
16 \\
\end{tabular}} & \multirow[t]{2}{*}{$\begin{array}{l}\text { Infra- } \\
\text { struc- } \\
\text { ture } \\
11\end{array}$} & \multirow{2}{*}{$\begin{array}{l}\text { Fees } \\
\\
0 \\
\end{array}$} & \multirow[t]{2}{*}{\begin{tabular}{|l} 
I do \\
not \\
know
\end{tabular}} & \multirow{2}{*}{$\begin{array}{l}\text { Total } \\
\\
65 \\
\end{array}$} \\
\hline \multirow{16}{*}{ Male } & \multirow{14}{*}{$\begin{array}{l}\text { Living } \\
\text { place of } \\
\text { partici- } \\
\text { pants? }\end{array}$} & \multirow{2}{*}{ Petrovaradin } & Count & & & & & & \\
\hline & & & $\%$ of Total & $24.2 \%$ & $10.5 \%$ & $7.2 \%$ & $0 \%$ & $0.7 \%$ & $42.5 \%$ \\
\hline & & \multirow{2}{*}{ Banstol } & Count & 2 & 4 & 0 & 0 & 0 & 6 \\
\hline & & & $\%$ of Total & $1.3 \%$ & $2.6 \%$ & $0 \%$ & $0 \%$ & $0 \%$ & $3.9 \%$ \\
\hline & & \multirow{2}{*}{ Ledinci } & Count & 6 & 9 & 3 & 0 & 0 & 18 \\
\hline & & & $\%$ of Total & $3.9 \%$ & $5.9 \%$ & $20 \%$ & $0 \%$ & $0 \%$ & $11.8 \%$ \\
\hline & & \multirow{2}{*}{$\begin{array}{l}\text { Sremska } \\
\text { Kamenica }\end{array}$} & Count & 4 & 8 & 7 & 0 & 0 & 19 \\
\hline & & & $\%$ of Total & $2.6 \%$ & $5.2 \%$ & $4.6 \%$ & $0 \%$ & $0 \%$ & $12.4 \%$ \\
\hline & & \multirow{2}{*}{$\begin{array}{l}\text { Sremski } \\
\text { Karlovci }\end{array}$} & Count & 1 & 1 & 3 & 9 & 7 & 21 \\
\hline & & & $\%$ of Total & $0.7 \%$ & $0.7 \%$ & $20 \%$ & $5.9 \%$ & $4.6 \%$ & $13.7 \%$ \\
\hline & & \multirow{2}{*}{ Čortanovci } & Count & 4 & 0 & 3 & 6 & 0 & 13 \\
\hline & & & $\%$ of Total & $2.6 \%$ & $0 \%$ & $20 \%$ & $3.9 \%$ & $0 \%$ & $8,5 \%$ \\
\hline & & \multirow{2}{*}{ Erdevik } & Count & 1 & 0 & 5 & 4 & 1 & 11 \\
\hline & & & $\%$ of Total & $0.7 \%$ & $0 \%$ & $3.3 \%$ & $2.6 \%$ & $0.7 \%$ & $7.2 \%$ \\
\hline & \multirow{2}{*}{\multicolumn{3}{|c|}{ Total }} & 55 & 38 & 32 & 19 & 9 & 153 \\
\hline & & & & $35.9 \%$ & $24.8 \%$ & $20.9 \%$ & $12.4 \%$ & $5.9 \%$ & $100 \%$ \\
\hline \multirow{16}{*}{$\begin{array}{l}\mathrm{Fe}- \\
\text { male }\end{array}$} & \multirow{14}{*}{$\begin{array}{l}\text { Living } \\
\text { place of } \\
\text { partici- } \\
\text { pants? }\end{array}$} & \multirow{2}{*}{ Petrovaradin } & Count & 7 & 19 & 9 & 0 & 4 & 39 \\
\hline & & & $\%$ of Total & $7.3 \%$ & $19.8 \%$ & $9.4 \%$ & $0 \%$ & $4.2 \%$ & $40.6 \%$ \\
\hline & & \multirow{2}{*}{ Banstol } & Count & 1 & 9 & 1 & 0 & 0 & 11 \\
\hline & & & $\%$ of Total & $10 \%$ & $9.4 \%$ & $10 \%$ & $0 \%$ & $0 \%$ & $11.5 \%$ \\
\hline & & \multirow{2}{*}{ Ledinci } & Count & 1 & 6 & 4 & 0 & 1 & 12 \\
\hline & & & $\%$ of Total & $10 \%$ & $6.3 \%$ & $4.2 \%$ & $0 \%$ & $10 \%$ & $12.5 \%$ \\
\hline & & \multirow{2}{*}{$\begin{array}{l}\text { SremskaKa- } \\
\text { menica }\end{array}$} & Count & 1 & 1 & 2 & 0 & 1 & 5 \\
\hline & & & $\%$ of Total & $10 \%$ & $10 \%$ & $2.1 \%$ & $0 \%$ & $10 \%$ & $5.2 \%$ \\
\hline & & \multirow{2}{*}{$\begin{array}{l}\text { SremskiKar- } \\
\text { lovci }\end{array}$} & Count & 1 & 2 & 0 & 7 & 0 & 10 \\
\hline & & & $\%$ of Total & $10 \%$ & $2.1 \%$ & $0 \%$ & $7.3 \%$ & $0 \%$ & $10.4 \%$ \\
\hline & & \multirow{2}{*}{ Čortanovci } & Count & 1 & 3 & 0 & 8 & 1 & 13 \\
\hline & & & $\%$ of Total & $10 \%$ & $3.1 \%$ & $0 \%$ & $8.3 \%$ & $10 \%$ & $13.5 \%$ \\
\hline & & Erdevik & Count & 2 & 3 & 1 & 0 & 0 & 6 \\
\hline & & & $\%$ of Total & $2.1 \%$ & $3.1 \%$ & $10 \%$ & $0 \%$ & $0 \%$ & $6.3 \%$ \\
\hline & \multirow{2}{*}{\multicolumn{3}{|c|}{ Total }} & 14 & 43 & 17 & 15 & 7 & 96 \\
\hline & & & & $14.6 \%$ & $44.8 \%$ & $17.7 \%$ & $15.6 \%$ & $7.3 \%$ & $100 \%$ \\
\hline
\end{tabular}

Source: Own calculations

After examining the Table 6 it can be concluded that there is a statistically significant difference in responses. Bearing in mind the importance of the percentage of participants' answers, the authors try to obtain the detailed information in the respect of the individual responses. Subsequently, this led to the question of how to carry outlocal economic development. Taking into account the overall percentage of the responses, especially in the field 
of attracting investments and building material base of tourism, the answer would be that it is directly working on building economic competitiveness of the local area in order to improve its economic future. Giving priority to the local economy and increasing competition is of the highest importance since the success of the community depends on their adaptation to the market environment that is rapidly changing and is increasingly competitive.

Table 7. Pearson Chi-Square Test

\begin{tabular}{|l|l|l|l|}
\hline \multirow{4}{*}{$\begin{array}{l}\text { Pearson Chi- } \\
\text { Square Test }\end{array}$} & Value & df & Statistical significance $(\mathrm{p})$ \\
\cline { 2 - 4 } & 124.020 & 24 & 0.000 \\
\cline { 2 - 4 } & Value & df & Statistical significance $(\mathrm{p})$ \\
\cline { 2 - 4 } & 69.668 & 24 & 0.000 \\
\hline
\end{tabular}

Source: Own calculations

The results can be seen in Table 8 showing that the Government of Vojvodina is taking some measures in encouraging the development of tourism on Fruška Gora Mountain. It is clear that success fulprivate enterprises create wealth in local communities. However, the achievement of prosperity of a private company depends on favourable local business conditions. This shows that local governments have an essential role in creating a favourable environment for business success. Therefore the lower-level hypothesis: h2 - Tourism attracts more investment in the region is confirmed.

Table 8. Support for the developmentof tourismin the AutonomousProvince of Vojvodina budget for the year 2019 .

\begin{tabular}{|l|r|r|}
\hline \multicolumn{1}{|c|}{ Tourism revenue budget } & $\begin{array}{l}\text { Losses and expens- } \\
\text { es from revenues, in- } \\
\text { come and unexpended } \\
\text { funds transferred/din }\end{array}$ & Total/din \\
\hline Services under the contract & $\mathbf{1 3 . 2 0 6 . 0 0 0 , 0 0}$ & $13.206 .000,00$ \\
\hline Subsidies to public financial institutions & $\mathbf{1 . 5 0 0 . 0 0 0 , 0 0}$ & $1.500 .000,00$ \\
\hline Subsidies to private companies & $\mathbf{1 1 2 . 0 0 0 . 0 0 0 , 0 0}$ & $112.000 .000,00$ \\
\hline Transfers to other levels of government & $\mathbf{3 0 . 0 0 0 . 0 0 0 , 0 0}$ & $30.000 .000,00$ \\
\hline Buildings & $\mathbf{1 8 . 0 0 0 . 0 0 0 , 0 0}$ & $18.000 .000,00$ \\
\hline Grants to non-government organizations & $\mathbf{3 8 . 0 0 0 . 0 0 0 , 0 0}$ & $38.000 .000,00$ \\
\hline $\begin{array}{l}\text { Total for the Encouragement of tourism develop- } \\
\text { ment in the Autonomous Province of Vojvodina }\end{array}$ & $\mathbf{2 1 2 . 7 0 6 . 0 0 0 , 2 1}$ & \\
\hline
\end{tabular}

Source: research of the authors

The experts from the Institute for Urban Planning of Vojvodina were planning that the tunnel entrance will beat Paragovo, and the exit will be in Irig. This would protect the areafrom pollution, and the tunnel would bring multiple benefits.The existing road will servefor visiting historic sites, mainly monasteries. Therefore, the improvement of the existing infrastructure for business and households, including roads, transportation, industrial and drinking water, waste disposal, energy systems, telecommunications systems, equipment for the prevention of crime (for example, street lighting), commercial and industrial areas, the beauty of the community (parks) is the answer to the question of how and in what way 
infrastructure has an impact on the local community. Therefore the lower-level hypothesis: h4 - Tourism has led to an increase of infrastructure for local people is confirmed.

A small proportion of participants $(13.2 \%)$ responded that the fees from tourism are something that would have a positive effect on the development of their communities. The research has shown that charging fees for entry into a protected natural area of Fruška Gora Mountain in the amount of 150 dinars was implemented on 21 April 2012. This fee includes the fee to enter the vehicle, lighting fires and using the parking lot in the park. In case the quality of environmental is burdened by a large number of vehicles, the fee makes sense. The money raised is exclusivelyearmarked for thesalaries ofpublic companies thatare custodiansof protected areas (foresters, biologists) and for the preservation and improvement of the area. Therefore the lower-level hypothesis: h5 - There should be a specific tax on tourists is confirmed.

The research has shown that the development of tourism had another advantage in the economicd evelopment of local communities, and that is cross-border cooperation. Fruška Gora Mountain is located in the municipality of Petrovaradin, Sremski Karlovci, Beočin, Bačka Palanka, Šid, Sremska Mitrovica, Irig and Inđija. The data on interregional cooperation in 2011 was provided by the four municipalities. Due to its border position with Croatia, it is clear that the best chance for cross-border cooperation lies in that fact. In 2011 the documents were signed and projects and donations from The Republic of Croatia were implemented-one letter of intent (Rijeka), one treaty of friendship and cooperation (City of Vukovar) and three projects of total value of $€ 1,170,995.37$.

First and foremost, transfrontier co-operation is a form of co-operation within crossborder "service and employment areas" traversed by all kinds of flows. In addition to this initial approach, it is important to bear in mind the wide variety of co-operation arrangements and projects, with an emphasis on cross-border cooperation. Therefore the lower-level hypothesis: h6 - Tourism development would have an impact on crossborder cooperation was confirmed.

\section{Conclusion}

The results suggest that the development of tourism must be the basis in the engagement of local communities and the coordination of this process is one of the most important levers in the business of local government leaders. This statement was confirmed by all six lower-level hypothesis (Tourism creates more jobs, Tourism attracts more investment in the region, Tourism has led to an increase in infrastructure for local people, The fees provide better conditions for the development of tourism and Tourism development would have an impact oncross-border cooperation). Where as it is obvious that tourism development is a priority, many local communities in Serbia still can not cope with it. In this particular case, the essential commitment of local communities in the mountain shows that they are making an attempt to use most of the resources for the long-term benefits - in the direction of economic development. For local management it is a challenge to present its decision to the public, then to gain support and 
to persist in the implementation. We can see that this is possible only if they clearly explain the specific and long-term benefits of investing in the local community development programs as well as support programs for tourism development and human resource development. The attitude of the local community is to make an effort to attract new investment, help existing enterprises to develop, promote small and medium enterprises and/or establish programs for self-employment or starting a small business.

Therefore, the development of tourism is their choice which will result in employment, strengthening the economic structure and the general improvement of life. This makes up the process of local economic development, whereby the main hypothesis that tourism has a positive economic effecton the local residents is confirmed. It is contended that a "happy host" is essential to elicit a positive image of the destination and to generate positive word of mouth.

Tourism human resource studies (or merely tourism employment impact assessments) are generally a reflection of the manifestations of tourism as a stimulus for economic growth. Once an economy becomes largely dependent on tourism, a decline in the tourism market can be devastating. Globalization has increased the opportunities and competition for investments, financial aid, business attraction andretention. It offers opportunities for local businesses to develop new markets and also presents challenges from international competitors entering the local markets. Manufacturing, banking and service corporations that are located in multiple locations compete globally to locate a profitable area for manufacturing operations and operations management services. Technologically advanced industries require highly specialized skills nd technology infrastructure.

Local conditions determine the advantage of the community and thus its ability to attract and retain investment. It is clear how muchpriority is given tothe destinations whereit is possible to develop tourism, such as Fruška Gora Mountain. However, reaching the term "developed tourism" is not an easy task and requires cooperation and interaction of many factors of the tourism industry. All this, of course, has an impact on the local community itself. The state regulatory, tax andother legal structures have an influence on shaping the climate for domestic companies, which can help or hinder the goals of local economic development (for example, deregulation of telecommunications standards for the environment). Globally, governmental functions are decentralized, and private industry has become"free". This usually has local economic consequences.

Local communities need to be awareof the dangers but also theopportunities that they provide. Communities within and between regions competeto attract external as well as domestic investment. There are many opportunities for communities (rural and urban) to collaborate with each other in order to help their economies. This will improve the overall competition in the regional economy, while their own economies will benefit at the same time. The most important and most effective initial development activity that municipalitie make take is to improve the processes and procedures through which companies must passon the city level. A brief over view of most local governments has disclosed a large number of complex, poorly managed, expensive and unnecessary systems of registration of companies. The reduction in the negative aspects will soon make the area improve its investment environment and become known as favourable for business operations. 


\section{Conflict of interests}

The authors declare no conflict of interest.

\section{References}

1. Almeida-Santos, C., \& Buzinde, C. (2007). Politics of identity and space. Representational dynamics. Journal of Travel Research, 45(3), 322-332. https:// doi.org/10.1177/0047287506295949

2. Andriotis, K., \& Vaughan, R. (2003). Urban residents' attitudes toward tourism development: The case of creta. Journal of Travel Research, 42(2), 172-185. http://dx.doi.org/10.1177/0047287503257488v

3. Berić, D., \&J ovičić, A. (2012). Cruising tourism Novi Sad and Belgrade residents' experience analyse. Journal of the Geographical Institute "Jovan Cvijić" SASA, 62(2), 67-80. https://doi.org/10.2298/IJGI1202067B

4. Bramwell, B. (2011). Governance, the state and sustainable tourism: a political economy approach. Journal of Sustainable Tourism, 19(4/5), 459-477. https://doi. org/10.1080/09669582.2011.576765

5. Brankov, J., Jovičić, D., \&Milijašević, D. (2015). Sustainable Tourism in National Park "Đerdap", Serbia - Attitudes of Local Population. Journal of the Geographical Institute "Jovan Cvijić" SASA, 65(2), 183-199. https://doi. org/10.2298/IJGI1502183B

6. Chen, J.S. (2000). An Investigation of Urban Tourism Residents' Loyalty of Tourism. Journal of Travel and Tourism Research, 24(1), 5-19. https://doi. org/10.1108/09596110110381870

7. Cross-border programme Croatia-Serbia. Retrieved from www.croatia-serbia.com (January 21, 2020).

8. Dubois, C.L.Z., \& Dubois, D.A. (2012). Strategic HRM as social design for environmental sustainability in organization. Human resource management, 51(6), 799-821. https://doi.org/10.1002/hrm.21504

9. Gajić, T., Vujko, A., Tretiakova, N.T., Petrović, M., Radovanović, M., \& Vuković, D. (2019). Evaluation of service quality and development of rural tourism - (Serbia) Case Study. Deturope - The Central European Journal of Regional Development and Tourism, 11(2), 4-22.

10. Gajić, T., Vujko, A., Petrović, M.D., Mrkša, M., \& Penić, M. (2018). Examination of regional disparity in the level of tourist offer in rural clusters of Serbia. Economics of Agriculture, 65(3), 911-929. https://doi.org/10.5937/ekoPolj1803911G

11. Hung-Lee, T., \& Haun-Jan, F. (2019). Can community-based tourism contribute to sustainable development? Evidence from residents' perceptions of the sustainability. Tourism Management, 70, 368-380. https://doi.org/10.1016/j.tourman.2018.09.003 
12. Ishikawa, N., \& Fukushibe, M. (2006). Who expects the municipalities to take initiative in tourism development? Residents' attitudes of AmamiOshima Island in Japan. Tourism Management, 28, 461-475. https://doi.org/10.1016/j. tourman.2006.03.008

13. Kuvan, Y., \& Akan, P. (2005). Residents' attitudes toward general and forest-related impacts of tourism: the case of Belek, Antalya. Tourism Management, 26(5), 691706. https://doi.org/10.1016/j.tourman.2004.02.019

14. Lepp, A. (2007). Residents' attitudes towards tourism in Bigodi village, Uganda. Tourism Management, 28(3), 876-885. https://doi.org/10.1016/j. tourman.2006.03.004

15. Latkova, P., \& Vogt, C.A. (2012). Residents' attitudes toward existing and future tourism development in rural communities. Journal of Travel Research, 51, 50-67. https://doi.org/10.1177/0047287510394193

16. Liu, A., \& Wall, G. (2006). Planning tourism employment: a developing country perspective. Tourism management, 27(1), 159-170. https://doi.org/10.1016/j. tourman.2004.08.004

17. Mason, P., \& Cheyne, J. (2000). Residents attitudes to proposed tourism development. Annals of Tourism Research, 27(2), 391-411. https://doi.org/10.1016/ S0160-7383(99)00084-5

18. McGehee, N., \& Andereck, K. (2004). Factors predicting rural residents' support of tourism. Journal of Travel Research, 43(2), 131-140. https://doi. org/10.1177/0047287504268234

19. Ministry of Finance and economy, Republic of Serbia. Retrieved from www.mfp. gov.rs (January 21, 2020).

20. Mitchell, R.E., \& Reid, D.G. (2001). Community Integration: Island Tourism in Peru. Annals of Tourism Research, 28(1), 113-139. https://doi.org/10.1016/S01607383(00)00013-X

21. Nunkoo, R., \&Ramkissoon, H. (2011). Developing a community support model for tourism. Annals of Tourism Research, 38(3), 964-988. https://doi.org/10.1016/j. annals.2011.01.017

22. Purcell, M., \& Nevins, J. (2005). Pushing the boundary: state restructuring, state theory, and the case of US: Mexico border enforcement in the 1990s. Political Geography, 24(2), 211-235. https://doi.org/10.1016/j.polgeo.2004.09.015

23. Podovac, M., Đorđević, N., \& Milićević, S. (2019). Rural tourism in the function of life quality improvement of rural population on Gočmountain. Economics of Agriculture, 66(1), 205-221. https://doi.org/10.5937/ekoPolj1901205P

24. Ryan, C., \& Cave, J. (2005). Structuring destination image: A qualitative approach. Journal of Travel Research, 44(2), 143-150. https:/doi. org/10.1177/0047287505278991 
25. Ruhanen, L. (2013). Local government: facilitator or inhibitor of sustainable tourism development. Journal of Sustainable Tourism, 21(1), 80-98. https://doi.or $\mathrm{g} / 10.1080 / 09669582.2012 .680463$

26. Saveriades, A. (2000). Establishing the Social Tourism Carrying Capacity for theTourist Resorts of the East Coast of the Republic of Cyprus. Tourism Management, 21(2), 147-156. https://doi.org/10.1016/S0261-5177(99)00044-8

27. Schoroeder, T. (1996). The relationship the residents' image of their state as a tourist destination and their support for tourism. Journal of Travel Research, 34(4), 71-74. https://doi.org/10.1177/004728759603400411

28. Srdanović, M., \& Pavić, D. (2015). Tourists' attitudes on tourism offer in northwestern part of Montenegro.Journal of the Geographical Institute "Jovan Cvijić" SASA, 65(2), 97-108. https://doi.org/10.2298/IJGI1502201S

29. Szivas, E., Riley, M., \& Airey, D. (2003). Labor mobility into tourism: attraction and satisfaction. Annals of Tourism Research, 30(1), 64-76. https://doi.org/10.1016/ S0160-7383(02)00036-1

30. Vargas-Sanchez, A., Porras-Bueno, N., \& Plaza-Mejia, A. (2010). Explaining residentsatitudes to tourism, is a universal model possible. Annals of Tourism Research, 38(2), 460-480. https://doi.org/10.1016/j.annals.2010.10.004

31. Vojvodina Investment Promotion. Retrieved from www.vip.org.rs (January 21, 2020).

32. Vujko, A., \& Plavša, J. (2014). Evaluation of National Park Fruška Gora (Serbia) for sport and recreational tourism. ActageographicaSlovenica, 54(2), 321-334. https://doi.org/10.3986/AGS54206

33. Vujko, A., Gajić, T., Penić, M., \& Petrović, M. (2019). Development Perspectives of Rural Tourism Policy - a Comparative Study of Rural Tourism Competitiveness Based on Perceptions of Tourism Workers in Slovenia and Serbia. Eastern European Countryside, 24(1), 144-154. https://doi.org/10.2478/eec-2018-0007

34. Vujko, A., Delić-Jović, M., Zečević, S.O., Zečević, L., \& Nedeljković, D. (2020). Gastronomy as a mean of marketing management and rural destination development. Serbian Journal of Engeenering Management, 5(1), 1-13. https:// doi.org/10.5937/SJEM2001001V

35. Vuković, D., Vujko, A., Maiti, M., \& Riad, S. (2019). Residents' perceptions of wine tourism on the rural destinations development. British Food Journal, 122(8), 2739-2753. https://doi.org/10.1108/BFJ-04-2019-0291

36. Vunjak, M.N., Vujko, A., Dragosavac, M., \& Antonijević, N.T. (2020): Descriptive statistics in corporate management and employee engagement in rural destinations. Economics of Agriculture, 67(4), 1087-1101. https://doi.org/10.5937/ ekoPolj2004087V

37. Zhang, J., Inbakaran-Robert, J., \& Jackson-Mervyn, S. (2006). Understanding community attitudes towards tourism and host-guest interaction in the urbanrural border region. Tourism Geographies, 88(2), 182-204. https://doi. org/10.1080/14616680600585455 